\title{
Preparation and characterization of yttria stabilized zirconia (YSZ) films deposited by dip-coating on LSM-YSZ substrate with different proportions
}

Jacqueline Costa Marrero ${ }^{1}$, Mariana de Mattos Vieira Mello Souza ${ }^{1}$, Célia de Fraga Malfatti ${ }^{2}$

\footnotetext{
${ }^{1}$ Escola de Química, Universidade Federal do Rio de Janeiro (UFRJ), Centro de Tecnologia, Bloco E, sala 206, Ilha do Fundão, CEP 21941-909, Rio de Janeiro, RJ, Brazil.

${ }^{2}$ Departamento de Metalurgia, Universidade Federal do Rio Grande do Sul (UFRGS), Campus do Vale, Setor 4, Prédio 75, Sala 234, CEP 91501-970, Porto Alegre, RS, Brazil.

e-mail: jacquecosta@gmail.com, mmattos@eq.ufrj.br, materiaisxenergia@gmail.com
}

\begin{abstract}
In this work, sol-gel/dip-coating process for obtaining yttria stabilized zirconia (YSZ, $\mathrm{ZrO}_{2}-8 \% \mathrm{Y}_{2} \mathrm{O}_{3}$ ) films deposited onto LSM-YSZ (lanthanum strontium manganite (LSM, La ${ }_{0.7} \mathrm{Sr}_{0.3} \mathrm{MnO}_{3}$ ) mixed with YSZ) with different proportions $(20 / 80,50 / 50,80 / 20)$ was investigated. The films were deposited on substrate varying the number of layers deposited.

LSM powders were obtained by the combustion method using metal nitrates and urea and YSZ was commercial. LSM-YSZ composite powders were obtained by the solid state method, through ball-milling of a mixture of LSM-YSZ (mass ratio) powder for $4 \mathrm{~h}$ with $500 \mathrm{rpm}$ using $\mathrm{ZrO}_{2}$ balls as milling media. For LSMYSZ substrate a study of sintering temperature was performed, where the optimum sintering temperature for each LSM-YSZ studied proportion was obtained. According to our results, it was found that $1100{ }^{\circ} \mathrm{C}$ is the optimum sintering temperature for $20 / 80,950{ }^{\circ} \mathrm{C}$ is the optimum sintering temperature for $50 / 50$ and $900{ }^{\circ} \mathrm{C}$ is the optimum sintering temperature for $80 / 20$ because of the good phase formation.

The films were characterized by X-ray Diffraction (XRD) and Scanning Electron Microscopy (SEM). The films showed LSM, YSZ, $\mathrm{SrZrO}_{3}$ and $\mathrm{La}_{2} \mathrm{O}_{3}$ phases. Crack-free, homogeneous and well adhered films were obtained with a thickness between 3 and $38 \mu \mathrm{m}$. In this work, YSZ films with appropriate thickness were obtained for application as SOFC electrolyte.
\end{abstract}

Keywords: YSZ films, LSM-YSZ substrate, SOFC, Dip-coating.

\section{INTRODUCTION}

Fuel cells are energy-conversion devices that convert the chemical energy of a fuel gas directly to electrical energy, with high efficiency and negligible production of pollutants [1]. When compared with conventional methods of power generation, solid oxide fuel cells (SOFCs) have many advantages, such as substantially higher conversion efficiency, easy modular construction, wide range of fuel possibilities, potential for cogeneration, and low maintenance cost [1,2]. The current focus in research in SOFCs is material development and reduced-temperature operation.

The most used materials in SOFCs are Ni/YSZ cermets as anode, lanthanum manganite doped with $\mathrm{Sr}\left(\mathrm{La}_{1-}\right.$ $\left.{ }_{x} \mathrm{Sr}_{\mathrm{x}} \mathrm{MnO}_{3}, \mathrm{LSM}\right)$ as cathode and yttria-stabilized zirconia $\left(\mathrm{ZrO}_{2}-8 \% \mathrm{Y}_{2} \mathrm{O}_{3}, \mathrm{YSZ}\right)$ as the electrolyte. LSMYSZ composites are also studied as SOFC cathode because the addition of YSZ to LSM substrate improves the electrochemical performance due to an increase of the triple phase boundary (TPB) area, extending the electrode reaction sites and significantly reducing electrode polarization and enlarging the electrolyte/electrode interface [3,4]. Moreover, there is a significant enhancement of the catalytic activity of the electrode using LSM-YSZ composites and an improved adhesion between the film and the substrate due to the intimate sintering of YSZ particles to the LSM-YSZ substrate [5,6].

In comparison to other fabrication methods, deposition of thin films by dip-coating technique is an easy, simple and inexpensive method, it offers a potential route for SOFC electrolyte preparation, and makes the process very attractive and economical for potential large-scale commercial fabrication [7]. The dip-coating can 
be used to synthesize homogeneous thin films of multi-component oxides [8] and is considered as an effective and practical method to produce YSZ films $[9,10]$.

There are no reports in the literature about the dip-coating deposition of YSZ films on LSM-YSZ substrates; only using another technique. YSZ films with a thickness of $10 \mu \mathrm{m}$ were deposited on LSM-YSZ 50/50 using DC magnetron sputtering [6]. CHEN and LIU [5] used electrophoretic deposition (EPD) to prepare YSZ films onto LSM-YSZ 80/20 (weight ratio) and dense, crack and pinhole-free films with a thickness of about $10 \mu \mathrm{m}$ were obtained.

In this paper, thin YSZ films were deposited on LSM-YSZ substrate by the dip-coating technique. Firstly, it was investigated the sintering temperature for preparation of LSM-YSZ composite substrates, and then YSZ films were dip-coated onto these substrates, varying the number of layers deposited. We studied YSZ films on LSM-YSZ substrates with different proportions, this is important because the adhesion between LSMYSZ substrate and YSZ thin layer depends on YSZ content of the substrate.

\section{MATERIALS AND METHODS}

\subsection{Material preparation}

$\mathrm{La}_{0.7} \mathrm{Sr}_{0.3} \mathrm{MnO}_{3}$ (LSM) powder was prepared by the combustion method using metal nitrates and urea, as described by CONCEIÇÃO et al. [11]. LSM-YSZ composite powders were prepared through ball-milling of a mixture 20/80, 50/50, 80/20 (weight ratio) LSM/YSZ (Saint-Gobain Norpro) powders for $4 \mathrm{~h}$ using $\mathrm{ZrO}_{2}$ balls as milling media, at room temperature, with speed of $500 \mathrm{rpm}$. The powders were calcined in air (60 $\mathrm{mL} / \mathrm{min}$ ) at $750^{\circ} \mathrm{C}$ for $10 \mathrm{~h}$ at $10^{\circ} \mathrm{C} / \mathrm{min}$.

The LSM-YSZ powders were then pressed into pellets (13 $\mathrm{mm}$ diameter and $2 \mathrm{~mm}$ thickness) under uniaxial pressure of $200 \mathrm{MPa}$. The pellets were sintered at different temperatures between $850{ }^{\circ} \mathrm{C}$ and $1300{ }^{\circ} \mathrm{C}$, at a heating rate of $10^{\circ} \mathrm{C} / \mathrm{min}$ for $2 \mathrm{~h}$, in order to choose the optimum sintering temperature of each substrate. The LSM-YSZ $20 / 80$ substrate was sintered at $1000{ }^{\circ} \mathrm{C}, 1100^{\circ} \mathrm{C}, 1200{ }^{\circ} \mathrm{C}$ and $1300{ }^{\circ} \mathrm{C}$, the LSM-YSZ 50/50 substrate was sintered at $8500^{\circ} \mathrm{C}, 950{ }^{\circ} \mathrm{C}, 1000^{\circ} \mathrm{C}$ and $1300{ }^{\circ} \mathrm{C}$ and the LSM-YSZ $80 / 20$ substrate was sintered at $850{ }^{\circ} \mathrm{C}, 900{ }^{\circ} \mathrm{C}, 950{ }^{\circ} \mathrm{C}$ and $1000{ }^{\circ} \mathrm{C}$. After that, the surface of the fired pellets was sanded with $\mathrm{SiC}$ paper (4000 mesh) and polished.

YSZ film precursors were prepared by a polymeric sol-gel process. The solution of metal salts was prepared from $\mathrm{Zr}\left(\mathrm{NO}_{3}\right)_{2}$ and $\mathrm{YCl}_{3} .6 \mathrm{H}_{2} \mathrm{O}$ (Acros Organics) with concentration of $\mathrm{Cs}=1 \mathrm{~mol} / \mathrm{L}$. An organic solution consisting of complexing and polymeric agents (hexamethylentetramin $\left(\mathrm{HMTA}-\mathrm{C}_{6} \mathrm{H}_{12} \mathrm{~N}_{4}\right.$ ), acetylacetone (acac- $\mathrm{C}_{5} \mathrm{H}_{8} \mathrm{O}_{2}$ ) and acetic acid (a.a.- $\mathrm{C}_{2} \mathrm{H}_{4} \mathrm{O}_{2}$ )), with Co concentration, was added to the metal salt solution to promote polyesterification and polycondensation reactions. $\mathrm{R}$, defined as $\mathrm{Co} / \mathrm{Cs}$ ratio, was 5 . The obtained sol was refluxed at $80^{\circ} \mathrm{C}$ on a hot plate until the desired viscosity $(100 \mathrm{cP})$ was reached.

The as-obtained YSZ gel was deposited on LSM-YSZ substrate at room temperature by the dip-coating technique. The withdrawal speed was $50 \mathrm{~mm} / \mathrm{min}$ and the time of deposition was of $40 \mathrm{~s}$. The films were dried at $70{ }^{\circ} \mathrm{C}$ for $30 \mathrm{~min}$ and then sintered at optimum sintering temperature of each substrate with a heating rate of 2 ${ }^{\circ} \mathrm{C} /$ min for $2 \mathrm{~h}$. It was deposited 1, 2 and 3 layers, with drying between successive depositions.

\subsection{Characterization}

The crystalline structure of material was analyzed by X-ray diffraction (XRD) using a Rigaku Miniflex II with $\mathrm{CuK} \alpha$ radiation and $2 \theta$ range from 10 to $90^{\circ}$. The XRD patterns were analyzed using JCPDS (Joint Committee on Powder Diffraction Standards) database of crystal structures. The crystallite sizes (D) and microstrain $(\varepsilon)$ were calculated using the equation (1) [12]:

$$
\beta \cos \theta / \lambda=1 / D+4 \varepsilon \sin \theta / \lambda
$$

where $\lambda$ is the X-ray wavelength $(0.154 \mathrm{~nm}), \theta$ is the Bragg diffraction angle and $\beta$ is the FWHM (full width at half maximum) of the peak.

Scanning electron microscopy (SEM) was carried out to characterize both morphology and microstructure of LSM-YSZ substrate and YSZ films, using a HITACHI TM-1000 microscopy. 


\section{RESULTS AND DISCUSSION}

\subsection{Characterization of LSM-YSZ substrate}

LSM-YSZ composite was sintered at four different temperatures in order to select the optimum sintering temperature to prepare the substrate. The XRD patterns are shown in Figure 1.
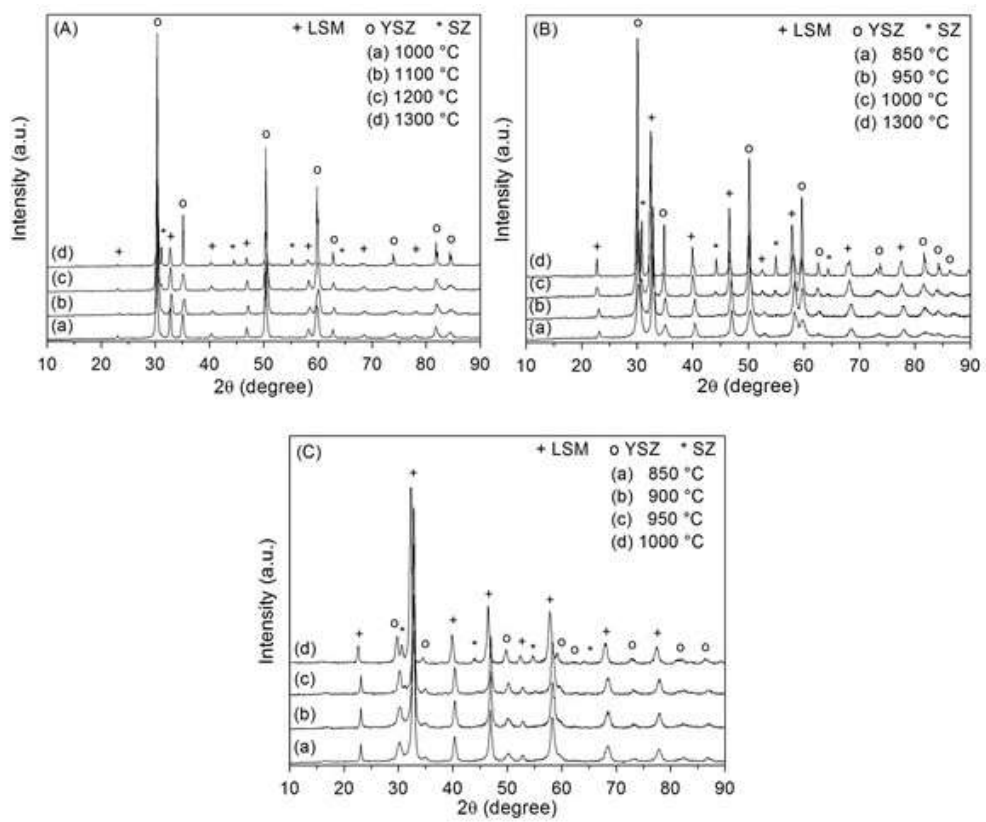

Figure 1: XRD patterns of the LSM-YSZ substrates after sintering for $2 \mathrm{~h}$ at $10{ }^{\circ} \mathrm{C} / \mathrm{min}$ at different temperatures and proportions: (A) 20/80, (B) 50/50 and (C) 80/20.

When the sintering temperature was $1000^{\circ} \mathrm{C}$ and $1100^{\circ} \mathrm{C}$ for $20 / 80,850{ }^{\circ} \mathrm{C}$ and $950{ }^{\circ} \mathrm{C}$ for $50 / 50$ and $850{ }^{\circ} \mathrm{C}$ and $900{ }^{\circ} \mathrm{C}$ for $80 / 20$, the diffraction peaks are identified as YSZ cubic phase (JCPDS 301468) and LSM perovskite phase (JCPDS 401100). The presence of any other phases was not detected; which indicates that YSZ and LSM do not react with each other during the synthesis process at these temperatures.

On the other hand, at sintering temperatures of $1200{ }^{\circ} \mathrm{C}$ and $1300{ }^{\circ} \mathrm{C}$ for $20 / 80,1000{ }^{\circ} \mathrm{C}$ and $1300{ }^{\circ} \mathrm{C}$ for $50 / 50$ and $950{ }^{\circ} \mathrm{C}$ and $1000{ }^{\circ} \mathrm{C}$ for $80 / 20$, there are additional peaks corresponding to the formation of $\mathrm{SrZrO}_{3}$ (SZ) phase (JCPDS 44161), due to the high-temperature reactions between LSM and YSZ [13,14]. The SZ phase increases with increasing the sintering temperature. The presence of $\mathrm{SZ}$ and/or $\mathrm{La}_{2} \mathrm{Zr}_{2} \mathrm{O}_{7}$ (LZ) phases weakens the electrical contact of cathode/electrolyte because the conductivity of these zirconates is at least 2-3 orders of magnitude lower than that of YSZ electrolyte [15]. BRANT et al. [16] observed formation of $\mathrm{SZ}$ at the interface between YSZ and porous LSM after annealing over to $1200^{\circ} \mathrm{C}$. In fact, according to VAN ROOSMALEN and CORDFUNKE [17] the formation of SZ from $\mathrm{La}_{0.7} \mathrm{Sr}_{0.3} \mathrm{MnO}_{3}$ and $\mathrm{ZrO}_{2}$ is estimated to start at $1247^{\circ} \mathrm{C}$. Thus, it can be concluded that $1100{ }^{\circ} \mathrm{C}, 950{ }^{\circ} \mathrm{C}$ and $900{ }^{\circ} \mathrm{C}$ is the optimum sintering temperature for 20/80, 50/50 and 80/20, respectively, because of the good phase formation of the substrate without secondary phases.

Figure 2 shows the SEM micrographs of the surface of LSM-YSZ 20/80 substrate after calcination, sintering at $1100{ }^{\circ} \mathrm{C}$ and polishing with sandpaper. The calcined powder showed a porous structure with agglomeration of particles of different sizes, while in the sintered substrate the particle size is more uniform and the porosity is lower. After the polishing process, there was a significant improvement in the substrate surface, reducing the porosity and leaving a homogeneous surface. The same result was obtained in the other LSM-YSZ proportions studied. 

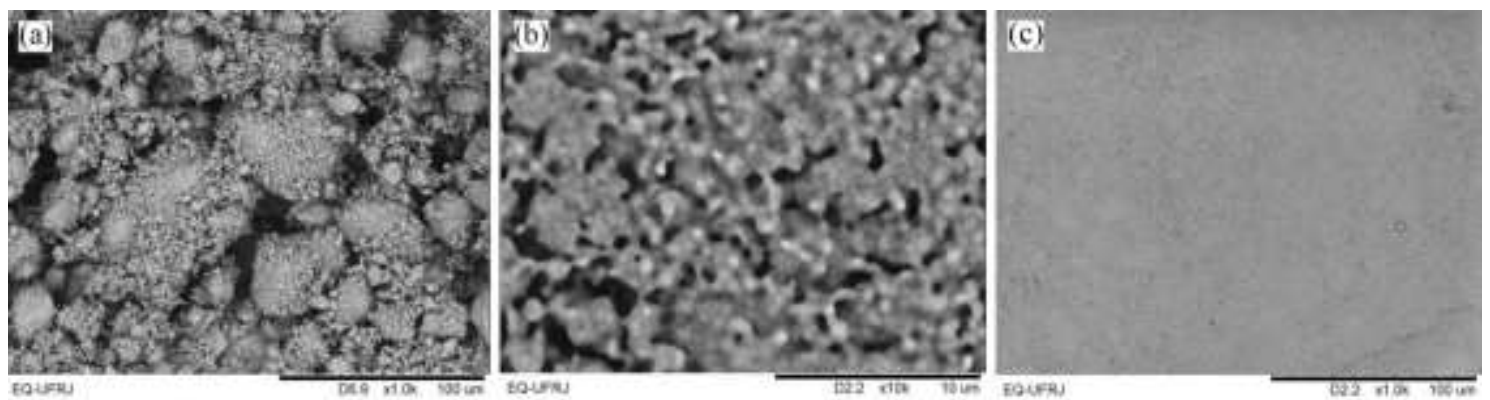

Figure 2: SEM micrographs of LSM-YSZ 20/80 substrate: (a) calcined, (b) sintered and (c) sanded.

\subsection{Characterization of YSZ films}

X-ray diffraction patterns of YSZ films deposited on LSM-YSZ 20/80, 50/50 and 80/20 substrates are presented in Figure 3 for different layers (1,2 and 3), after sintering at the optimum sintering temperature for each substrate $\left(1100{ }^{\circ} \mathrm{C}\right.$ for $20 / 80,950{ }^{\circ} \mathrm{C}$ for $50 / 50$ and $900{ }^{\circ} \mathrm{C}$ for $\left.80 / 20\right)$ for $2 \mathrm{~h}$ at $2{ }^{\circ} \mathrm{C} / \mathrm{min}$.
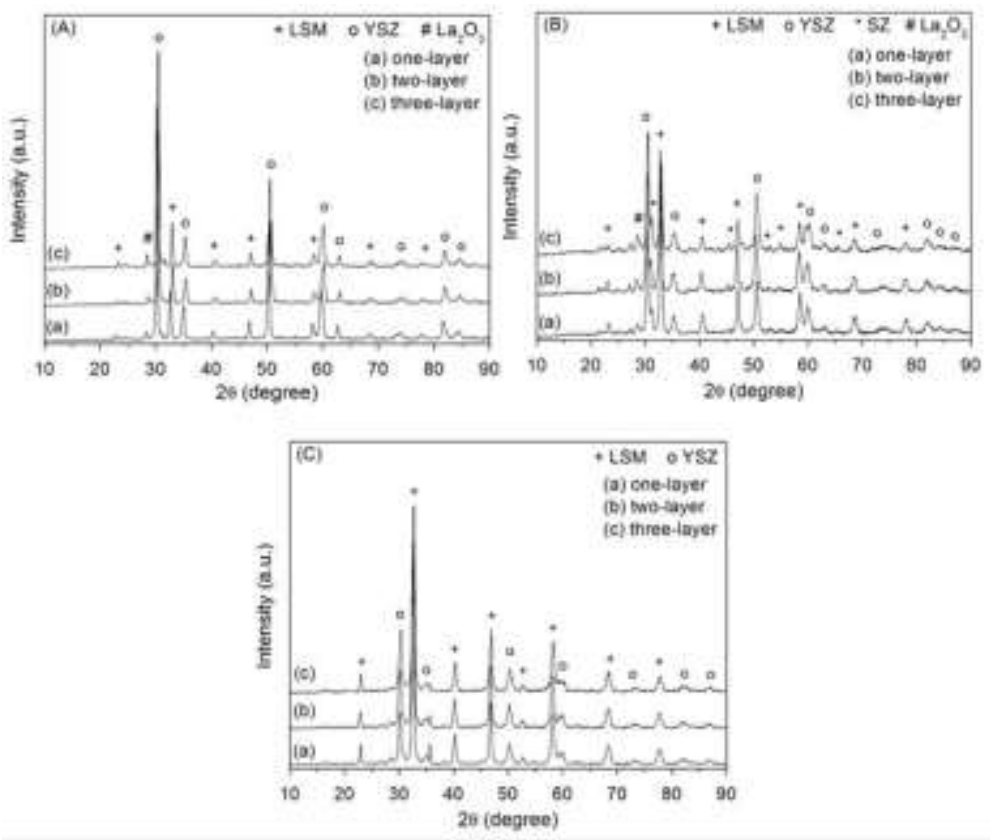

Figure 3: XRD patterns of YSZ film on LSM-YSZ substrates for one-layer, two-layers and three-layers, sintered at the optimum sintering temperature: (A) on $20 / 80$ at $1100{ }^{\circ} \mathrm{C}$, (B) on $50 / 50$ at $950{ }^{\circ} \mathrm{C}$, and $(\mathrm{C})$ on $80 / 20$ at $900{ }^{\circ} \mathrm{C}$.

The XRD patterns are similar for all layers and all LSM-YSZ proportions, showing the cubic YSZ and LSM phases. For LSM-YSZ 20/80 and 50/50 substrates there are a small diffraction peak at $28.5^{\circ}$, which may be attributed to $\mathrm{La}_{2} \mathrm{O}_{3}$ (JCPDS 22641). The formation of this secondary phase is more pronounced for the threelayer sample, because the weaker interaction between the film and the substrate favors perovskite decomposition to simple oxides. The slow heating rate used for sintering after film deposition may enhance LSM decomposition to $\mathrm{La}_{2} \mathrm{O}_{3}$, however the heating rate of $2{ }^{\circ} \mathrm{C} / \mathrm{min}$ used was due to the values of the sintering temperatures used $\left(<1200{ }^{\circ} \mathrm{C}\right)$, moreover films at higher heating rate were made and the YSZ films showed cracks. For LSM-YSZ 50/50 substrate is also the formation of SZ phase.

The average crystallite size and microstrain of the YSZ phase calculated from XRD data of films are reported in Table 1. The increase in the number of layers does not significantly affect the average crystallite size and microstrain, indicating that the crystallinity of the YSZ films does not change with the number of layers. 
Table 1: Crystallite sizes and microstrain of YSZ films on LSM-YSZ substrate.

\begin{tabular}{l|l|l|l}
\hline LSM-YSZ SUBSTRATE & LAYERS & CRYSTALLITE SIZES (nm) & MICROSTRAIN (\%) \\
\hline $20 / 80$ & 1 & 35,8 & 0,32 \\
\hline $20 / 80$ & 2 & 33,4 & 0,33 \\
\hline $20 / 80$ & 3 & 34,3 & 0,33 \\
\hline $50 / 50$ & 1 & 18,3 & 0,59 \\
\hline $50 / 50$ & 2 & 19,4 & 0,58 \\
\hline $50 / 50$ & 3 & 18,2 & 0,66 \\
\hline $80 / 20$ & 1 & 23,3 & 0,49 \\
\hline $80 / 20$ & 2 & 20,4 & 0,54 \\
\hline $80 / 20$ & 3 & 22,1 & 0,50 \\
\hline
\end{tabular}

Figure 4 shows the cross-section microstructure of the YSZ film on LSM-YSZ 20/80 substrate sintered at $1100{ }^{\circ} \mathrm{C}$, on LSM-YSZ 50/50 substrate sintered at $950{ }^{\circ} \mathrm{C}$ and on LSM-YSZ 80/20 substrate sintered at $900{ }^{\circ} \mathrm{C}$ for one-layer, two-layer and three-layer. As observed from the SEM images, dense and crack-free films, with a substrate/film interface well defined, were obtained for all layers. With increasing the number of layers, the film thickness becomes more homogeneous.
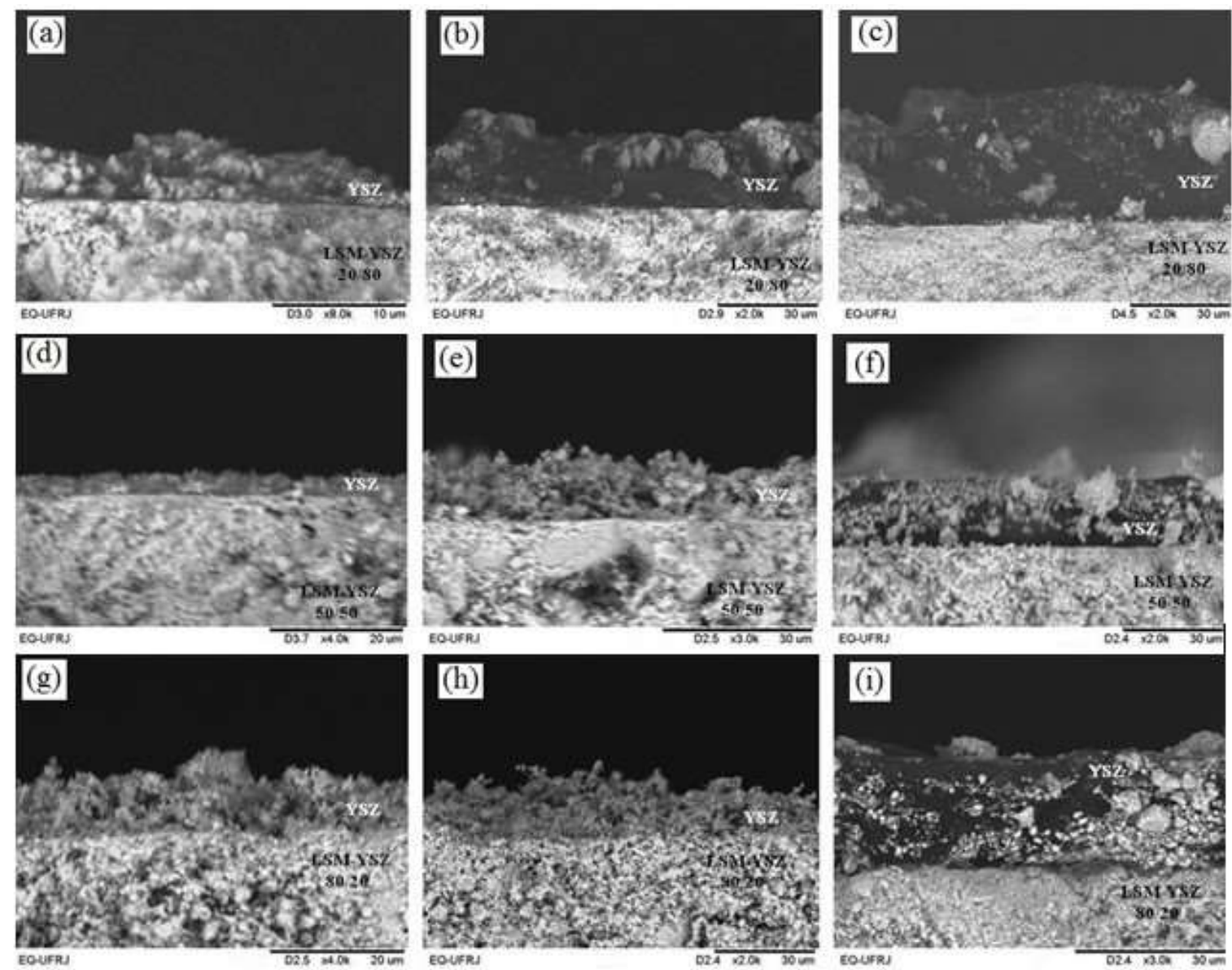

Figure 4: Cross-sectional microstructures of YSZ film on LSM-YSZ substrates sintered at the optimum sintering temperature for different layers and proportions: (a) one-layer sample on 20/80, (b) two-layer sample on 20/80, (c) threelayer sample on 20/80, (d) one-layer sample on 50/50, (e) two-layer sample on 50/50, (f) three-layer sample on 50/50, (g) one-layer sample on 80/20, (h) two-layer sample on 80/20 and (i) three-layer sample on 80/20. 
The thickness of the YSZ film on LSM-YSZ 20/80, 50/50, 80/20 substrates for one-layer, two-layer and three-layer sample are reported in Table 2. For all substrates, the thickness of the YSZ films is proportional to the number of layers, as expected. Some authors have obtained similar values of YSZ film thickness, but using other substrates or other deposition techniques. YANG et al. [18] have reported a thickness of the YSZ film deposited on the $\mathrm{La}_{0.8} \mathrm{Sr}_{0.2} \mathrm{MnO}_{3}$ substrate using the EPD method of about $16 \mu \mathrm{m}$. WANG et al. [19] have prepared YSZ thin films on NiO-YSZ anode substrates by dip-coating with different number of layers and the film thickness of one-layer sample was about $10 \mu \mathrm{m}$, of two-layer sample was $16 \mu \mathrm{m}$, and that of three-layer sample was $21 \mu \mathrm{m}$. In general, YSZ films of 5-30 $\mu \mathrm{m}$ are suitable for application as SOFC electrolyte [2].

Table 2: Thickness of YSZ films on LSM-YSZ 20/80, 50/50, 80/20 substrates for one-layer, two-layer and three-layer.

\begin{tabular}{l|l|l}
\hline LSM-YSZ SUBSTRATE & LAYERS & THICKNESS $(\boldsymbol{\mu m})$ \\
\hline $20 / 80$ & 1 & 3,8 \\
\hline $20 / 80$ & 2 & 24,6 \\
\hline $20 / 80$ & 3 & 38,0 \\
\hline $50 / 50$ & 1 & 3,5 \\
\hline $50 / 50$ & 2 & 12,5 \\
\hline $50 / 50$ & 3 & 20,4 \\
\hline $80 / 20$ & 1 & 10,1 \\
\hline $80 / 20$ & 2 & 17,7 \\
\hline $80 / 20$ & 3 & 23,1 \\
\hline
\end{tabular}

\section{CONCLUSIONS}

A study of the sintering temperature of LSM-YSZ 20/80, 50/50, 80/20 substrates was performed, and, according to our results, $1100{ }^{\circ} \mathrm{C}$ is the optimum sintering temperature for $20 / 80,950{ }^{\circ} \mathrm{C}$ is the optimum sintering temperature for $50 / 50$ and $900{ }^{\circ} \mathrm{C}$ is the optimum sintering temperature for $80 / 20$ because of the good phase formation. The dip-coating process was used to prepare YSZ films deposited on LSM-YSZ substrate, with one, two or three layers. XRD results of the films sintered at the optimum sintering temperature for each substrate showed: cubic YSZ and LSM perovskite phases, besides a small formation of $\mathrm{La}_{2} \mathrm{O}_{3}$ secondary phase for 20/80 substrate; YSZ, LSM, $\mathrm{La}_{2} \mathrm{O}_{3}$ and SZ phase for 50/50 substrate and YSZ and LSM phase for $80 / 20$ substrate. Homogeneous, dense, continuous, and crack-free YSZ films were obtained with a thickness between 3 and $38 \mu \mathrm{m}$.

To prepare YSZ films deposited on LSM-YSZ substrate, the optimum LSM-YSZ substrate is $80 / 20$, because for all layers: 1) the films showed LSM and YSZ phases without secondary phases, 2) the film thickness of 10-23 $\mu \mathrm{m}$ are suitable for application as SOFC electrolyte, 3) this proportion have sufficient electrical conductivity for electrode application, according to the literature.

\section{ACKNOWLEDGMENTS}

The authors thank CAPES for financial support granted to carry out this work.

\section{BIBLIOGRAPHY}

[1] STAMBOULI, A.B, TRAVERSA, E., "Solid oxide fuel cells (SOFCs): a review of an environmentally clean and efficient source of energy", Renewable and Sustainable Energy Reviews, v. 6, n. 5, pp. 433-455, Oct. 2002.

[2] SINGHAL, S.C., KENDALL, K., High Temperature Solid Oxide Fuel Cells: Fundamentals, Design and Applications, New York, Elsevier, 2004.

[3] HONG, S.A, NAM, S.W., "Application of sol-gel techniques in fabrication of fuel cells", Studies in Surface Science and Catalysis, v. 159, pp. 79-84, 2006.

[4] HAANAPPEL, V.A.C., MERTENS, J., RUTENBECK, D., TROPARTZ, C., HERZHOF, W., SEBOLD, D., TIETZ, F., "Optimisation of processing and microstructural parameters of LSM cathodes to improve the electrochemical performance of anode-supported SOFCs", Journal of Power Sources, v. 141, n. 2, pp. 216226, March. 2005. 
[5] CHEN, F., LIU, M., "Preparation of yttria-stabilized zirconia (YSZ) films on $\mathrm{La}_{0.85} \mathrm{Sr}_{0.15} \mathrm{MnO}_{3}$ (LSM) and LSM-YSZ substrates using an electrophoretic deposition (EPD) process", Journal of the European Ceramic Society, v. 21, n. 2, pp. 127-134, Feb. 2001.

[6] TSAI, T., BARNETT, S.A., "Effect of LSM-YSZ cathode on thin-electrolyte solid oxide fuel cell performance", Solid State Ionics, v. 93, n. 3-4, pp. 207-217, Jan. 1997.

[7] ZHANG, Y., GAO, J., PENG, D., GUANGYAO, M., LIU, X., "Dip-coating thin yttria-stabilized zirconia films for solid oxide fuel cell applications”, Ceramics International, v. 30, n. 6, pp. 1049-1053, 2004.

[8] PAN, Y., ZHU, J.H., HU, M.Z., PAYZANT, E.A., "Processing of YSZ thin films on dense and porous substrates", Surface \& Coatings Technology, v. 200, n. 5-6, pp. 1242-1247, Nov. 2005.

[9] PARralEJO, A.D., GARCÍA, A.M., GONZÁLEZ, J.S., DÍEZ, M.A.D., CORREA, E.M.C., "Influence of the experimental parameters on the synthesis process of yttria-doped zirconia sol-gel films", Surface \& Coatings Technology, v. 204, n. 14, pp. 2257-2261, Apr. 2010.

[10] LENORMAND, P., CARAVACA, D., ROBERT, C.L., ANSART, F., “Thick films of YSZ electrolytes by dip-coating process", Journal of the European Ceramic Society, v. 25, n. 12, pp. 2643-2646, 2005.

[11] CONCEIÇÃO, L., RIBEIRO, N.F.P., FURTADO, J.G.M., SOUZA, M.M.V.M., "Effect of propellant on the combustion synthesized Sr-doped $\mathrm{LaMnO}_{3}$ powders", Ceramics International, v. 35, n. 4, pp. 1683-1687, May. 2009.

[12] WILLIANSON, G.K., HALL, W.K., "X-ray line broadening from filed aluminum and wolfram”, Acta Metallurgica, v. 1, n. 1, pp. 22-31, Jan. 1953.

[13] LABRINCHA, J.A., FRADE, J.R., MARQUES, F.M.B., " $\mathrm{La}_{2} \mathrm{Zr}_{2} \mathrm{O}_{7}$ formed at ceramic electrode/YSZ contacts", Journal of Materials Science, v. 28, n. 14, pp. 3809-3815, Jan. 1993.

[14] STOCHNIOL, G., SYSKAKIS, E., NAOUMIDIS, A., "Chemical compatibility between strontiumdoped lanthanum manganite and yttria-stabilized zirconia", Journal of the American Ceramic Society, v. 78, n. 4, pp. 929-932, Apr. 1995.

[15] LIU, Y.L., HAGEN, A., BARFOD, R., CHEN, M., WANG, H.J., POULSEN, F.W., HENDRIKSEN, P.V., "Microstructural studies on degradation of interface between LSM-YSZ cathode and YSZ electrolyte in SOFCs", Solid State Ionics, v. 180, n. 23-25, pp. 1298-1304, Oct. 2009.

[16] BRANT, M.C., MATENCIO, T., DESSEMOND, L., DOMINGUES, R.Z., "Electrical degradation of porous and dense LSM/YSZ interface", Solid State Ionics, v. 177, n. 9-10, pp. 915-921, Mar. 2006.

[17] VAN ROOSMALEN, J.M., CORDFUNKE, E.H.P., "Chemical reactivity and interdiffusion of (La, $\mathrm{Sr}) \mathrm{MnO}_{3}$ and $(\mathrm{Zr}, \mathrm{Y}) \mathrm{O}_{2}$, solid oxide fuel cell cathode and electrolyte materials”, Solid State Ionics, v. 52, n. 4, pp. 303-312, Jun. 1992.

[18] YANG, K., SHEN, J.H., YANG, K.Y., HUNG, I.M, FUNG, K.Z., WANG, M.C., "Characterization of the yttria-stabilized zirconia thin film electrophoretic deposited on $\mathrm{La}_{0.8} \mathrm{Sr}_{0.2} \mathrm{MnO}_{3}$ substrate", Journal of Alloys and Compounds, v. 436, n. 1-2, pp. 351-357, Jun. 2007.

[19] WANG, Z., SUN, K., SHEN, S., ZHANG, N., QIAO, J., XU, P., "Preparation of YSZ thin films for intermediate temperature solid oxide fuel cells by dip-coating method", Journal of Membrane Science, v. 320, n. 1-2, pp. 500-504, Jul. 2008.

\section{ORCID}

Jacqueline Costa Marrero

Mariana de Mattos Vieira Mello Souza

Célia de Fraga Malfatti https://orcid.org/0000-0002-6951-4355

https://orcid.org/0000-0003-3958-7665

https://orcid.org/0000-0002-0819-479X 